\title{
THE NEEDS OF ELDERLY YUGOSLAVS IN THE MELBOURNE METROPOLITAN AREA
}

\author{
SUMMARY
}

The paper presents a sociological discussion on the problems and needs of older generation immigrants (over 60 years of age) born in Yugoslavia and living in the greater Melbourne area in a milieu which is new and which includes the younger immigrant generation. Proceeding from an analysis of the demographic profile of the samples, the author gives an objective critical evaluation of all the main. (economic, health-related, cultural, social, educational etc.) problems of the older generation. A separate section of the text treats the complex problem of the realisation of specific recent needs of the older immigrant generation.

\subsection{Introduction}

This study constitutes an introduction to the environmental dynamics and socio-cultural characteristics of the Yugoslav-born senior citizens ${ }^{1}$ who live in the Melbourne metropolitan area. The report is based on the $1984-85$ study by the same title, which was instigated by the Australian Yugctilav Welfare Scciety (AYWS) and funded by the Victorian Ethnic Affairs Commission. All facets of the research were carried out by the present author including the construction of the questionnaire and interview schedule, the collection of data by the interviewing technique, the computer analysis of the data, the interpretation of the analyzed data and the writing up of the results. It reports on the research into the needs of the Yugulslav-born senior citizens with regard to social interaction, recreation, health, welfare, domiciliary services and accommodation. All the statistical data quoted in the original report, relating to the Yugoslav community in Australia was drawn from the 1981 Census, which showed that there were 3,285 Yugoslav-born senior citizens, 60 years of age and over, living in Melbourne in 1981. With the availability of the 1986 Census data it is evident that the number of Yugoslav-born senior citizens living in Melbourne had reached 6,078 by 1986 . Thus, the number of Yugoslav-born senior citizens has almost doubled in just five years. According to the proljected

1 The term: Yugoslav-born senior citizens, refers to people aged 60 or more who were born in the geographical area representing present day Yugoslavia including the peoples of Bosnia and Herzegovina, Croatia, Macedonia, Montenegro, Serbia and Slovenia (Appedix A p.25). People younger than 60 years of age with similar disadvantages to their chronologically counterparts were also included in the sample population. Generally, but not exclusively, an elderly person is someone who can no longer work. 
statistics compiled by the Australian Institute of Multicultural Affairs (2) the proportion of Yugoslav-born senior citizens in Australia will continue to spiral at an alarming rate which will, during the next decade, significantly exceed the proportion of Australian-bctrn senior citizens (see Table 1, p.3).

The aim of this paper is to stimulate community planning affecting senior citizens of non-English speaking background in general and of Yugoslav background in particular. The examination and analysis of the needs of Yugoslav-born senior citizens is a first step in the prcless of identifying the inadequacies of existing services and of providing a blue-print for the expansion and improvement of these and the introduction of new mainstream and ethno-specific services. This development must be seen as an urgent priority for the Yugoslav community, particularly in view of the demographic trends which shc'w that by the year 2001, approximately one third of the Yugoslav-born men and women in Australia will be aged 60 years and over.

Apart from having to face significant life cycle transitions in marital status, health, employment and income, common to all Australian senior citizens, it must be reclgnized that the overseas born non-English speaking senior citizens experience further social disadvantages because of increasing language difficulties and other specifics associated with cultural characteristics.

While one of the three biggest non-English speaking communities, following the Italians and preceding the Greeks, the Yugoslavs are further disadvantaged than these two groups because they are more ethnically diverse. The then minister for Ethnic Affairs, the Honourable Peter Spyker, clearly stated at a meeting with various Yugoslav groups, held in March 1988, that funds will be allckated preferably to groups who show that they can 'coordinate' themselves. It is essential that the Yugoslav community work more closely together and especially with regard to issues which are primarily existential in nature such as education and welfare with this study particularly focusing on services for the aged. Only then can they expect the maximum sympathy and appreciation as well as moral and financial support from their own and the mainstream communities.

\subsection{The Yugoslav-born Populatictn in Australia}

Although the first people from the geographical area now known as Yugoslavia migrated to Australia as early as the 1850 s, large scale immigration from Yugoslavia did not begin until after World War II. Census data show that the Yugoslavs immigrated to Australia, predominantly in twol'migration waves'.

The first wave, which took place following World War II, comprising of 'displaced persons' included people from forced labour camps, men married to ethnic Germans and other individuals who feared reprisals following the Partisan victclry. Foroed to leave or prevented from returning to their homeland due to political pressure, this group were labelled the 'political $m^{i}$ grants'.

The second wave of migration took place during Australia's rapid economic grcwth during the late $1960 \mathrm{~s}$ and early $70 \mathrm{~s}$. This group was referred to as the 'economic migrants' and comprised of relatively young, strong and healthy unskilled and semi-skilled labourers.

As the labour market became saturated, changes were made to Australia's immigration policy which resulted in the discontinuation of large scale immigration. Appendix B graphically shows a sharp decline in the number of Yugoslav-born immigrants arriving to Australia after 1972. Since this time, and as a matter of course, the Yugoslav community has undergone a dramatic shift 
towards an aging populaticm. While this phenomenon affected the first migration wave already in the 1970 s, this demographic process will continue to affect the second migration wave in the immediate future.

Statistical data compiled by the Australian Institute of Multicultural Affairs (2), based on the 1981 Census, strongly support the above contention. The statistics show that in 1981 the Yugoslav-born population aged 60 years and over represented nine percent of the total Yugclslav-born population in Australia, while the proportion of the Australian-born population aged 60 years and over comprised 13 percent of the tctal Australian-born population. However, the projected proportion of the Yugoslav-born population aged 60 years and over is estimated to reach 17 percent by 1991 and 30 percent by the year 2001 , while the proportion of the Australian-born pcpulation aged 60 years and over for the same periods is estimated to remain constant at 14 and 13 percent respectively (see Table 1).

The table indicates that the proportion of the Yugoslav-born population aged 60 years and over is estimated tol more than double during the next decade. That these projections are accurate may be gauged from the more recent 1986 Census data which show that the proportion of the Yugoslav-born aged 60 years and over has increased to over $12 \%$ of the total Yugoslav-born pctpulation in Australia while the proportion to the Australian-born aged 60 years and over was recorded at below $14 \%$ of the total Australian-born population.

\section{Table 1}

Estimated and projected proportions of the Yugoslav-born population and the Australian-born population aged 60 years and over: Australia 1981, 1986, 1991 and 2001. (Source: Australian Institute of Multicultural Affairs, 1983)

\begin{tabular}{lrrrr}
\hline & \multicolumn{3}{c}{ Year } \\
\hline & 1981 & 1986 & 1991 & 2001 \\
\hline $\begin{array}{l}\text { Yugoslav-born population } \\
\text { aged 60 and over }\end{array}$ & $9 \%$ & $12.3 \%$ & $17 \%$ & $30 \%$ \\
$\begin{array}{l}\text { Australian-born population } \\
\text { aged 60 and over }\end{array}$ & $13 \%$ & $13.9 \%$ & $14 \%$ & $13 \%$ \\
\hline
\end{tabular}

It follows then, that while the demand for accommodation, domiciliary services, senior citizen centres, health and welfare services and so on, will remain relatively unchanged among the Australian-born populatictn aged 60 years and over, the demands for such services can be expected to double among the Yugoslav-born senior citizens.

The under-representation of Yugoslavs and other non-English speaking communities in their use of presently available mainstream facilities and services (as shown by Brewer, (4) and Hearst, (11) does not imply that the Yugoslav community does not require such services. It is dangerous to believe that migrant elderly do not need mainstream services because the extended family will help them (13). It is appropriate to ask whether these services meet the needs of the Yugoslav community. The main purpose of this report is to research this question.

The Yugoslav ocmmunity, like many other European communities hold strong traditional family values. The 'macro structure' of institutions needs to recognise and support these traditional family values by developing services that would enable ethnic families to maintain their own traditions and ca- 
re for their frail and aging parents at home. This is becoming exceedingly more difficult in the Australian comtext where the nuclear family rather than the extended family is the norm. It is important to note that unless these services are developed to meet the needs of Yugoslav-born senior citizens, the growing number of Yugoslav-born senjior citizens will either be left to their own goud fortunes or misfortunes, or they will turn to their own community agencies and service providers fictr support. However, it is highly unrealistic at present to believe that Yugoslav service providers could cope with an increased demand. Brewer $(4: 88)$ also reports that, "The case for ethnic organizations running an array of domiciliary services for aged pecple seems only to exist because of the apathy or wilful neglect of some local government authorities«. Furthermore, the Yugosiav community should not be held entirely responsible for the care of their community members with relation to health, welfare, recreational, domiciliary and accommodation needs.

\subsection{Research methodology}

As a first step in acquiring relevant data a semi-structured interview schedule and questionnaire ${ }^{2}$ were devised. Both were designed with the aim to ascertain the needs of the Yugoslav-born senior citizens as they themselves perceived them. The interviewing technique utilized a social approach, allowing the informants, wherever pcissible, to perform the role of hosts. Most interviews were conducted in the informants home or place of residence which provided a setting in which the informants not only felt comfortable but also had maximum control over the interview situation. The semi-structured interview schedule which was administered first, enabled informants to express in their k/wn personal way the most significant experiences in their lives and individual methods of coping with changing circumstances as well as alerting the interviewer of their greatest concerns. These were further taken up in the questionnaire phase of the interview. The interviews were taped with the interviewees permission. With only a few exceptions, the tape recorder was well received and proved extremely useful in preventing loss of information. In the few cases where the interviewee objected $t c$ l the use of the tape-recorder, the interviews were transcribed directly on paper.

The questionnaire was administered immediately following the interview schedule and covered areas such as demographic data, problems with health, social interaction: including leisure and recreational activities, educational level, employment experience, economic status, living arrangements, dietary habitas and knowledge and use of existing services. Appendix C provides a selected sample of the questionnaire which is tco lengthy to include in its original form.

The interview schedule and questionnaire together required an average time of four hours to complete. It was established during the pilot study that informants coped well with this lengthy testing procedure and welcomed the opportunity to discuss their problems in detail, frequently volunteering infcrmation which was not asked for. Indeed, most were extremely grateful that someone was interested to listen to their problems.

Seventy interviews were varried out in the above outlined manner and were subsequently computer analyzed using the Statistical Packages for the Sclcial Sciences (SPSS).

2 The complete semi-structured interview schedule and questionnaire are set out in Appendices $M$ and $N$ respectively of the original report (3). 


\subsection{Selection of Sample}

The AYWS was the logical place to begin sampling. However, the author aimed to include a representative sample of the Yugoslav-born population in the study. This was achieved by extending the catchment area beyond those who had utilized the services provided by the AYWS, to include those who might nut have been aware of this community organisation. The later group were contacted through the ethnic radio and press, church organisations, $\mathrm{Yu}-$ goslav senior citizen centres and social clubs and through information leaflets which were disseminated through 23 schools in the Western, Northern and South-Eastern areas of Melbourne. The author aclnsulted the Ethnic Education Census (1983 data on Yugoslav Languages Schools Population) for the Eastern. Western and Northern metropolitan regions in order to determine the schools with the highest protportion of students of Yugoslav origin.

\subsection{Pilot Study}

Before cummencing the interviewing, it was necessary to test out the measuring instruments to affirm that the interview schedule and questionnaire were relevant to the population being tested, that they complemented one another and adequately covered all areas of interest without being unacceptably lengthy. It was also necessary to ensure that the measuring instrument was easily understok'd and did not contain ambiguities.

The interview procedure was applied to seven informants, four female and three male. Included in this sample were informants of Croatian, Macedonian, Serbian an Slovenian origin.

The interview schedule and questionnaire were revised on the basis of responses obtained in the pilot study. This included the semi-structuring and condensation uff the open-ended interview schedule as well as the deletion of a number of questions from the questionnaire and the refinement of the alternatives in the multiple-choise section.

\subsection{Results and Discussion}

\subsection{Demographic Profile of the Sample Population}

Of the seventy informants, 28 were male and 42 female. Table 2 delineates the ethnic background of the sample population.

Table 2

Yugoslav-born informants by birthplace

\begin{tabular}{lr}
\hline Birthplace & \\
\hline Bosnia and Herzegovina & 5 \\
Croatia & 21 \\
Macedonia & 16 \\
Montenegro & 2 \\
Serbia & 22 \\
Slovenia & 4 \\
\hline Total & 70 \\
\hline
\end{tabular}


The twc largest groups of informants originated from Serbia and Croatia, with another large group from Macedonia. The remaining informants originated from Bosnia and Herzegovina, Slovenia and Montenegro respectively. Over $55 \%$ of the sample population came from rural areas of Yugoslavia. Approximately equal priportions of the remaining informants came from town and city areas.

A quarter of the informants were aged less than 55 years of age, while half of the sample population were less than 60 years of age. Sixty-five percent of the informants had resided in Australia for a period between 10 and 21 years, the full range of the period of residency being between 3 and 30 years. These statistics correspond with the 1981 Census data on the Yugoslav-bitrn population in Melbourne (refer to Appendices D, E and F in the origtinal report). Table 3 provides a crosstabulation of the informants age by length of residence in Australia.

Table 3

Informants age by length of residence in Australia

\begin{tabular}{cccccccc}
\hline & \multicolumn{7}{c}{ Length of Residence in } \\
\hline $\begin{array}{c}\text { Informants } \\
\text { Present Age }\end{array}$ & 3 & $5-9$ & $10-14$ & $15-21$ & $22-28$ & $29+$ & $\begin{array}{c}\text { Row } \\
\text { Total }\end{array}$ \\
\hline$<55$ & - & 1 & 4 & 7 & 2 & - & 14 \\
$55-59$ & - & 2 & 4 & 5 & 3 & - & 14 \\
$60-64$ & 3 & 1 & 10 & 2 & 1 & 1 & 13 \\
$65-69$ & - & 2 & 1 & 2 & - & - & 5 \\
$70-74$ & - & 2 & 1 & 5 & 3 & - & 11 \\
$75-79$ & - & - & 2 & - & 1 & 1 & 4 \\
$80+$ & - & 2 & 1 & 1 & - & - & 4 \\
\hline Column Total & 3 & 10 & 23 & 22 & 10 & 2 & 70 \\
\hline
\end{tabular}

Over sixty percent of informants were aged between 35 and 55 years when they arrived to Australia. Eighty seven percent of inflrmants had acquired an Australian citizenship at the time of being interviewed. A further four percent were in the process of acquiring an Australian citizenship. The remaining informants had Yugoslav citizenship. These findings are supported by the statistical data of the 1986 Census of Population and Housing (Table CX0040 - Overseas Born Persons).

With regard to marital status, the analysis revealed that 33 informants were married, 1 was single, 21 widowed and 15 divorced k'r separated. Widowed females significantly outnumbered widowed males by $14: 2$. Divorced or separated females also significantly outnumbered divorced or separated males by 14:1. Eighty-five percent of informants reported having faced extreme difficulties following the death of their spouse or following a divcrce or separation. These difficulties included loneliness, shock, and for the women, problems with bringing up children as a single mother without financial assistance. Informants frequently turned to relatives and close friends for assistance during these times of crisis. Since infictrmants depend heavily on family in times of crisis it was important to investigate whether families could cope with these situations. 


\section{2 Support Network}

Eighty-five percent of informants had at least one child who lived in Melbourne. One third of these informants also had children living abroad, predominantly in Yugoslavia. Hotwever, ten percent were childless and a further five percent only had children living interstate or abroad. Thus, fifteen percent of informants had no immediate family to turn to in times of diffuculty or crisis.

Frequently, the informants immediate family members comprised their entire family network, both here in Australia and in general. Indeed, seventy percent of informants had ten or fewer relatives living in Melbourne.

A quantitative analysis of the informants family netwctrk is inadequate in itself to reveal the closeness of family ties and availability of support. The informants were therefore asked how often they had contact with their relatives in Melbourme and whether they considered this to be sufficient and personally satisfying.

Approximately eighty percent of informants replied they were satisfied with the amount of octntact they had with at least one of their sons. Informants had itwice as much contact with a son than with a daughter. In fact, they were more likely to live with a son than with a daughter.

Less than one third of informants had relations other than children and grandchildren who lived in Melbourne. Less than a quarter of respondents were satisfied with the amount of contact they had with extended family members.

Immediate family members in particular and cccasionally close friends, assisted the informants with accommodation, housework, laundry, cooking, handy man type jobs, transportation, shopping, outings, letter writing (in the native language), filling in forms and letter writing in English, aftercare following hospitalization as well as financially. Table 4 summarises the types and quality of assistance which the infermants in the sample population received from their family and friends.

Reciprocal assistance on the part of the informant was also looked at. Table 5 provides a summary of areas in which the informants assisted their children.

\subsubsection{Informants Level of Dependence}

Informants were asked on whom they depended upon the most. The majkirity of informants depended mostly upon a son $(35 \%)$. Twenty-one percent depended mostly on their daughter and a further $21 \%$ on a close friend. Nine percent of infirmants relied the most on a social worker. Among this group were informants who did not have family or close friends. The remaining informants relied the most upon their spctuse.

\subsubsection{Informants State of Loneliness}

Informants were asked how much time they spent on their own whether they generally felt lonely. Seven percent of informants reported being always alone, $37 \%$ were mostly alone and $17 \%$ were alone some of the time. The remaining $39 \%$ of the informants reported being rarely or never alone (see Table 6). 
Table 4

The number of informants receiving various forms of assistance from family and friends

\begin{tabular}{|c|c|c|c|c|}
\hline $\begin{array}{l}\text { Type of } \\
\text { assistance }\end{array}$ & $\begin{array}{l}\text { informants } \\
\text { assisted } \\
\text { by family }\end{array}$ & $\begin{array}{l}\text { informants } \\
\text { assisted } \\
\text { by friends }\end{array}$ & $\begin{array}{l}\text { No.of } \\
\text { informants } \\
\text { needing } \\
\text { assistance } \\
\text { but not } \\
\text { receiving } \\
\text { any }\end{array}$ & $\begin{array}{c}\text { No.of } \\
\text { informants } \\
\text { satisfied } \\
\text { with the } \\
\text { amount and } \\
\text { quality of } \\
\text { assistance } \\
\text { provided } \\
\text { by family }\end{array}$ \\
\hline Accommodation & 17 & 1 & 0 & 17 \\
\hline House Cleaning & 20 & 2 & 2 & 20 \\
\hline $\begin{array}{l}\text { Maintenance of } \\
\text { House \& Garden }\end{array}$ & 10 & 1 & 1 & 10 \\
\hline Laundry & 21 & 1 & 2 & 21 \\
\hline Cooking & 21 & 2 & 0 & 21 \\
\hline Transport & 23 & 4 & 4 & 22 \\
\hline Shopping & 12 & 1 & 2 & 12 \\
\hline $\begin{array}{l}\text { Provide clothing } \\
\text { and footwear }\end{array}$ & 1 & 0 & 0 & 1 \\
\hline Provide food & 12 & 1 & 0 & 11 \\
\hline Excursions & 20 & 5 & 4 & 19 \\
\hline Provide company & 33 & 43 & 2 & 30 \\
\hline Medical bills & 0 & 0 & 0 & 0 \\
\hline Finance/Expenses & 12 & 4 & 1 & 12 \\
\hline $\begin{array}{l}\text { Letter writing } \\
\text { (native tongue) }\end{array}$ & 8 & 0 & 3 & 8 \\
\hline $\begin{array}{l}\text { Letter writing } \\
\text { (English) }\end{array}$ & 38 & 14 & 10 & 35 \\
\hline $\begin{array}{l}\text { Aftercare/ } \\
\text { Hospitalisation }\end{array}$ & 1 & 0 & 0 & 1 \\
\hline
\end{tabular}

Informants were further asked to access their own state of loneliness. Twenty-eight percent stated that they generally felt lonely, with an additional $22^{\circ} \%$ of informants sometimes feeling lonely. Twenty-five percent of the informants stated that they rarely felt lonely and twenty-six percent that they never felt lonely. Loneliness, therefore, was a problem for half uf the informants. 
Table 5

Ways in which informants assisted ther children

\begin{tabular}{lcc}
\hline $\begin{array}{l}\text { Areas in which informants } \\
\text { helped their children }\end{array}$ & $\begin{array}{c}\text { Number of } \\
\text { informants } \\
\text { providing help }\end{array}$ & $\begin{array}{c}\text { Relative } \\
\text { Frequency } \\
(\%)\end{array}$ \\
\hline Accommodation & 10 & 14 \\
Housework & 16 & 23 \\
Handy man jobs & 8 & 11 \\
Laundry & 14 & 20 \\
Cooking & 23 & 33 \\
Child minding & 17 & 24 \\
Finance & 7 & 10 \\
Other & 5 & 7 \\
\hline
\end{tabular}

Table 6

Amount of time informants spent on their own.

\begin{tabular}{lcc}
$\begin{array}{l}\text { Duration of } \\
\text { Time Spent Alone }\end{array}$ & $\begin{array}{c}\text { Number of } \\
\text { Informants }\end{array}$ & $\begin{array}{c}\text { Relativ: } \\
\text { Frequency } \\
(\%)\end{array}$ \\
\hline Always alone & 5 & 7 \\
Mostly alone & 26 & 37 \\
Sometimes alone & 12 & 17 \\
Rarely alone & 9 & 13 \\
Never alone & 18 & 26 \\
\hline Total & 70 & 100 \\
\hline
\end{tabular}

\section{3 Recreational Activities}

Informants were asked how they spent their time. Watching television was listed as the most popular form of recreation followed by listening to ethnic radio, writing letters to relations living abrklad, cookting, listening to ethnic records and cassettes, gardening, needlecrafts, reading in the native language, reading in English, winemaking, visiting friends and relations, going to church and attending social clubs.

While cunly $3 \%$ of informants expressed the desire to join an Australian senior citizens centre, $3 \%$ were keen to join a Yugoslav senior citizens centre. This preference was attributed primarily to the language barrier and not being able to relate $t c^{\prime}$ the Australian way of life, including the playing of bowls. Other studies researching ethnic-Australians' (Hungarians, Italians and Poles) membership of clubs and organizations have also found a preference for belonging to ethnic rather than Anglo-Australian organisations particularly among the older generation and among those of monkLethnic background (16).

When questioned about the types of activities they would like to see introduced at the social clubs, they showed preference for excursions and planned retirement classes (discussions on issues relevant to them) but did not support activities such as handcrafts or playing bowls. Without input however, the Yugoslav senior citizens had difficulty initiating their own prolposals. 


\subsection{Personal Problems and Worries}

Informants were asked which of the following ceinstituted their greatest problems and worries: poor health, financial difficulties, loneliness, maintaining a house and garden or poor relations with their children. Poor health was of greatest concern to them follclwed by loneliness, finances and maintaining a house and garden. They had fewest worries pertaining to family relations.

In response to the question "What would provide you with the greatest relief in your present situation? «, improved health was listed as a high priority followed by ocmpanionship and financial security.

When asked about the happiest and most satisfying period in their lives, most informants answered that the birth of a grandchild was the most satisfying and happy period in their lives.

\subsection{Health Problems}

The most prevalent complaint among the Yugoslav senior citizens was poor eye sight, followed by arthritis/rheumatism, asthma, pclor hearing, cardiac disorders, nervous conditions, soreness in the limbs, back and neck injuries, diabetes and paralysis due to a stroke. Table 7 delineates the type and frequency of health problems which affected the sample population.

Table 7

Frequency and type of health problems affecting the sample population

\begin{tabular}{lcc}
\hline Nature of health problem & $\begin{array}{c}\text { No. of } \\
\text { informations } \\
\text { affected }\end{array}$ & $\begin{array}{c}\text { Relative } \\
\text { Frequency } \\
(\%)\end{array}$ \\
\hline Poor eye sight & 52 & 74.3 \\
Arthritis/Rheumatism & 29 & 41.4 \\
Asthma/respiratory diff. & 26 & 37.1 \\
Poor hearing & 25 & 35.7 \\
Vascular condition & 20 & 28.6 \\
Nervous condition & 17 & 24.3 \\
Pain in limbs & 14 & 20.0 \\
Back and neck pain & 13 & 18.6 \\
Diabetes & 3 & 4.3 \\
Paralysis (stroke) & 1 & 1.4 \\
\hline
\end{tabular}

It is apparent that most informants suffered from more than one ailment. One third of informants believed that one or more of their health conditions were directly related to past work experience. Among these problems were listed: back, neck, leg and arm injurties, poor hearing, breathing difficulties and a/rthritic/rheumatic pain.

\subsubsection{Eye Care}

During the course of the project, the author assisted a number of Yugoslav-born senior citizens affected by poor eye sight with the filling out of applicaton forms fcr free eye testing and spectacle makfing at the Royal Mielbourne Eye and Ear Hospital. None of the informants had previously heard of this service. However, a number of informants were dissatisfied with the one year waiting period and declimed to use the service on these grounds. 


\subsubsection{Hearing Care}

An authority on hearing care services was invited to speak to approxima tely forty Yugoslav-born senior citizens at the Reservoir centre. Following this information dissemination session, about a quarter of the group had their hearing tested and some were given further specialist treatment.

\subsection{Knowledge and Use of Existing Services}

The eye and hearing care services are examples cy just two mainstream services about which the informants in the sample population had not heard of. It was important to investigate whether the informants were any better informed about other mainstream services and whether they knew how to go about using these services. It would also be important to investigate whether mainstream services are apprctpriately geared to meet the needs of the Yugoslav-born senior citizens.

The analysis has shown that on the whole, the Yugoslav-born senicr citizens social network does not extend beyond their immediate family and close friends. It is therefore also important to access to what extent their relatives and friends are themselves aware of mainstream services and to what extent they approve of these services. Their level of positive attitude toward mainstream services was expected to influence the Yugoslav-born senior citizens use of such services in a positively correlated way.

Table 8 provides a summary of those services which the informants had heard of, the number if informants who used the service at the time of being interviewed as well as their own and their families receptiveness to using these services in times of need.

\section{Table 8}

Informants knowledge and use of existing services and level of family approval

\begin{tabular}{|c|c|c|c|c|c|}
\hline $\begin{array}{l}\text { Type of } \\
\text { Service }\end{array}$ & $\begin{array}{c}\text { Frequency } \\
\text { of infs. } \\
\text { who knew } \\
\text { of the } \\
\text { available } \\
\text { service }\end{array}$ & $\begin{array}{l}\text { Number } \\
\text { of infs. } \\
\text { who used } \\
\text { the service } \\
\text { at the time } \\
\text { of being } \\
\text { intervie- } \\
\text { wed }\end{array}$ & $\begin{array}{l}\text { Frequency } \\
\text { of infs. } \\
\text { willing } \\
\text { to use } \\
\text { the service } \\
\text { if the need } \\
\text { arose }\end{array}$ & $\begin{array}{l}\text { Families } \\
\text { approval } \\
\text { of the } \\
\text { informant } \\
\text { using the } \\
\text { service }\end{array}$ & $\begin{array}{l}\text { Frequency } \\
\text { of infs. } \\
\text { who } \\
\text { thought } \\
\text { their } \\
\text { families } \\
\text { would } \\
\text { object }\end{array}$ \\
\hline $\begin{array}{l}\text { Meals on } \\
\text { Wheels }\end{array}$ & $58 \%$ & $1 \%$ & $53 \%$ & $80 \%$ & $8 \%$ \\
\hline Home Help & $55 \%$ & $2 \%$ & $52 \%$ & $93 \%$ & $7 \%$ \\
\hline Home Nursing & $52 \%$ & $2 \%$ & $90 \%$ & $95 \%$ & $2 \%$ \\
\hline TIS* & $55 \%$ & $21 \%$ & $90 \%$ & $95 \%$ & $2 \%$ \\
\hline $\begin{array}{l}\text { Concessions on } \\
\text { Water/Rates } \\
\end{array}$ & $100 \%$ & $70 \%$ & $100 \%$ & $100 \%$ & 0 \\
\hline $\begin{array}{l}\text { Concession on } \\
\text { Gas/Electricity } \\
\text { (during winter) }\end{array}$ & $50 \%$ & $35 \%$ & $100 \%$ & $100 \%$ & 0 \\
\hline
\end{tabular}

* TIS-Telephone Interpreter Service 


\subsubsection{Meals on Wheels}

Three percent of informants stated they had tried the meals on wheels service in the past but had stopped using it because they were dissatisfied. According to the informants, the meals were not ethno-palatable.

There are a number of strategies which could be introduced in order to increase the receptiveness of Yugcslav-born senior citizens to the meals on wheels service. A number of these strategies are being successfully utilised by other non-English minority groups.

These include: a) the introduction of Yugoslav cuisine meals by mainstream Meals on Wheels service providers (in regions with a high Yugoslav-born population),

b) subcontracting Yugoslav restaurants,

c) preparation cif a few meals by a neighbour,

d) cooking in the informants home as part of a home visiting service,

e) introduce the Yugoslav-born elderly to this service through senior citizens centres and church organisations,

f) inform the general Yugoslav community about the availability of this service thrctugh the ethnic radio, television and newspapers.

\subsubsection{Dietary Needs}

Although some informants were required to exercise caution with regard to the intake of salt, fats, eggs and milk products, over eighty percent stated they ate mainly Yugoslav dishes which included pickled vegetables, smoked meats, charcoal grills and gravy dishes. Steam cooking and boiling vegetables was practised by fifteen percent of informants who usually followed this diet on medical advice. The fact that most informants primarily consumed Yugoslav dishes partially explains why they rarely used the meals on wheels service. On the one hand, the informants need to be educated about healty dietary practices. What is traditional may not necessarily be healthy. On the other hand, mainstream meals on wheels service providers need to be sensitive to the issue cff providing meals on wheels that are 'ethnopalatable' to their clientele. In this instance, even those informants who live in an extended family unit would be more tempted to make use of the meals on wheels service, thus relieving some to the pressure off their children who presently assist them with food preparation on a regular basis.

\subsubsection{Telephone Interpreter Service (TIS)}

With regard to the telephome interpreter service and the energy concessictns on gas and electricity during winter, a number of informants stated they did not know how to go about using these services. This fact highlights that information about such benefits needs to be publicised on ethnic radio and multicultural television (SBS), the who most widely used sources of media, as well as through public group meetings which could be organised through church and senior citizen centres.

\subsubsection{Use of Phone}

Eighty-eight percent of informants owned a phone and half used it daily. Informants who lived in an extended family situation frequently stated that 
they used the phone sparingly in order not tcl burden their families with the expense.

Quite a few informants felt uncomfortable in using the telephone, either because they had problems speaking the English language, hearing difficulties or lacked the motor skills essential for dialling. The Australian Telecommunications Commission rents a range 'cf devices intended to make the telephone accessible to those with hearing and motor skill difficulties including devices which amplify and 'touchphctnes' with push button operation.

Even with these aids the Yugoslav senior citizens living on their own, or left alone at home while the rest of the family go to work and school, may lack the knowledge of who to phone in an emergency or be able to express themselves. It is recommended that practical teaching sessions be organised at senior citizen centres to train people how to use the phone in emergency situations.

\subsection{Level of Education}

Eight percent of informants stated they had not received any formal education. Fifty-eight percent had received between one and four years of schooling. At that time, primary education consisted of four years of schooling. Of those who continued with secctndary schooling the average, total number of years of schooling completed was five. Only one informant furthered his qualifications in Australia and by completing a oneyyear course he became a boiler attendant. He had completed eight years of schooling in Yugoslavia, which constituted the ccmpletion of secondary education.

\subsubsection{Level of Literacy in the Native Language and English}

Two informants in the sample population reported being illiterate. Given that the Latin script is predominantly used in Croatia, Bosnia and Herzegovina and Slovenia, it was likely that an informant from these regions was unacquainted with the Cyrillic script. On the other hand, two informants from the English language. This is perinent even among the twenty percent of the could not use the Latin script.

It is of no surprise that the large majority of informants faced enormous difficulties in having to speak, and more so in having to read and write in the English language. This is pertinent even among the twenty percent of the sample population who had in the past attended part-time English classes. The majority had ocmpleted a one month course and two informants studied English for more than itwelve months. Table 9 summarises the informants level competence in the English language.

Table 9

Informants ability to speak, read and write English

\begin{tabular}{|c|c|c|c|}
\hline \multirow{2}{*}{$\begin{array}{l}\text { Level of } \\
\text { Competence }\end{array}$} & \multicolumn{3}{|c|}{ Language Skill } \\
\hline & $\begin{array}{l}\text { Speaking } \\
\text { English }\end{array}$ & $\begin{array}{l}\text { Reading } \\
\text { English }\end{array}$ & $\begin{array}{l}\text { Writing } \\
\text { English }\end{array}$ \\
\hline $\begin{array}{l}\text { Nil } \\
\text { Poor } \\
\text { Good }\end{array}$ & $\begin{array}{l}26 \% \\
57 \% \\
17 \%\end{array}$ & $\begin{array}{r}77 \% \\
18 \% \\
5 \%\end{array}$ & $\begin{array}{r}92 \% \\
8 \% \\
-\end{array}$ \\
\hline Total & $100 \%$ & $100 \%$ & $100 \%$ \\
\hline
\end{tabular}


Informants were furthermore asked whether they would like to study English mnow: Seventy-five percent considered that they were beyond the stage of being able to learn in a formal setting. Those who showed interest in improving their English skills were more concerned with conversation than with reading and writing. It is unreasonable to expect that Yugoslav-born senior citizens would benefit greatly from existing English as a Second Language (ESL) courses, on the basis of their low level of formal education in their native language. The Yugoslav-born senior citizens are willing to imprctve their English language skills but are further disadvantaged by the social context in which they live which is based around the extended family unit.

\subsection{Current Employment Situation}

Twenty percent of the informants in the sample population were unemployed. The remainder were retired except for two informants who worked full-jime. It is interesting to nicte that none of the retired informants did any paid work. Most were affected by poor health as is evident from the high frequency of relatively young persons in the sample group. This is further supported by the fact that over $60 \%$ of infermants had been retired or unable to work for at least two and sometimes ten years. In fact, almist half of the informants stated that they ceased working due to an injury sustained at work. Only eleven percent had neached pensionable age. The high incidence of injury sustained at work. Only eleven percent had reached pensionable age. The high incidence of injury sustained at work indicates an urgent need to carry out a comprehensive study in this area. It is strongly recommended that this important finding be taken up separately by the AYWS and other relevant institutions.

\subsection{Financial Situation}

Four informants were bound by the 'assurance of support' arrangement and had mo income at the time of being interviewed. They relied entirely on their families for financial assistance and other forms of support. The impact of total dependence was devastatingly felt by c'ne informant whose immediate family were unable to cope with the financial burden and ultimately abandoned the informant. A neighbour of Yugoslav origin, who found the informant wandering about the neighbourhood in a distressed state offered assistance by voluntarily providing the infermant with food and accommodation. The informant was later awarded the 'Special Benefit' on the grounds of proven hardship which more often than not involves considerable stress and embarrassment to the individual and the family. However, she continued to live with the sympathetic neighbour due to lack of language proficiency amcmg other factors. Similar hardships were experienced by another three informants all of whom sought assistance from AYWS. Moraitis, in his 1979 report (13: :402), also states that, $»$ Financial difficulties are often the major underlying factors in other problems experienced by aged immigrants, "... and frequently ... aggravate mental and physical stresses and increase sucial and physical isolation.« The elderly person feels $s / h e$ is a burden on the family if s/he has no financial independence. The present study revealed that over half of the informants had problems relating to financial commitments. 


\subsubsection{Major Source of Income}

Almost thirty percent of informants received an 'Invalid Pension'. Twenty -five percent received the 'Old Age Pension' and seventeen percent received the 'Widcws Pension'. Ten percent received the 'Special Benefit'. Two informants earned a wage and one received income from rent. Four informants received the 'War Veterans Pension', one the 'Sickness Benefit' and two the 'Unemployment Benefit'. Three respondents were without income at the time of being interviewed. Table 10 summarises these results.

Table 10

Informants major source of income

\begin{tabular}{llccc}
\hline & & $\begin{array}{c}\text { No. of } \\
\text { informants }\end{array}$ & $\begin{array}{c}\text { Relative } \\
\text { frequency }(\%)\end{array}$ \\
\cline { 1 - 2 } Pensioner & Invalid Pension & 20 & 28.6 \\
& Old Age Pension & 18 & 25.7 \\
& Widow Pension & 12 & 17.0 \\
& War Veterans Pension & 4 & 5.7 \\
\hline \multirow{2}{*}{ Unemployed } & Unemployment Benefit & 2 & 3.0 \\
& Sickness Benefit & 1 & 1.4 \\
& Special Benefit & 7 & 10.0 \\
& No income & 3 & 4.2 \\
\hline Employed & Wage & 2 & 3.0 \\
& Rent & 1 & 1.4 \\
\hline
\end{tabular}

Even those who have lived and worked in Australia for an extended period of time were not cctvered by superannuation or insurance. It is apparent that because migrants usually work in 'socially undesirable' jobs, their capacity to save and plan for their old age is minimal.

\subsection{Living Arrangements}

Fourteen percent of informants lived in an extended family unit, nine percent of these were with their son and five with their daughter. Forty, itwo percent of informants lived in their own home ir a home which they were purchasing. Thirteen percent rented private acoommadation while twenty-eight rented holusing commission, flat or independent living units. One informant lived in a special acoommodation home while another did not have permanent acoommodatich at the time of being interviewed. Table 11 summarises the informants present living arrangements.

When asked if they would consider changing their accommodation in the future, given that their health remained the same, seventy-five percent stated they would consider moving in with their son and his family. One informant had plans to move to an independent living unit and eight percent had the desire to move back to their homeland. The others did not think they vould move from their present place of residence.

Informants were also asked where they would consider moving to in the case they required constant care. Twenty-ifive percent stated they would move to their sons house and seventeen percent that they would mitve to their daughters house. The son appears to have the greater responsibility in caring for his parents. This may be because traditionally, the daughter-in-law came to live with her parents-in-llaw while the daughters left home when they 
Table 11

-Informants present living arrangements

\begin{tabular}{lcc}
\hline $\begin{array}{l}\text { Type of } \\
\text { accomodation }\end{array}$ & $\begin{array}{c}\text { No. of } \\
\text { informants }\end{array}$ & $\begin{array}{c}\text { Relative } \\
\text { frequency }(\%)\end{array}$ \\
\hline $\begin{array}{l}\text { Home owner/purchaser } \\
\text { (living 'independently) }\end{array}$ & 29 & 42.0 \\
\hline $\begin{array}{l}\text { Extended family } \\
\text { arrangement }\end{array}$ & 10 & 14.0 \\
\hline $\begin{array}{l}\text { Paying Rent } \\
\text { (Housing Commission) }\end{array}$ & 20 & 28.0 \\
\hline $\begin{array}{l}\text { Paying Rent } \\
\text { (Private) }\end{array}$ & 9 & 13.0 \\
\hline $\begin{array}{l}\text { Special Accommodation } \\
\text { No accommodation } \\
\text { (living with friend) }\end{array}$ & 1 & 1.5 \\
\hline Total & 1 & 1.5 \\
\hline
\end{tabular}

married to live with their in-laws. Indeed, some informants, particularly those cf Macedonian background expected that their sctn and daughter-in--law would live with them. Another explanation may be that because the male is seen as the dominant figure in the household, elderly parents feel they will get more respect from their own son than from a son-in-law.

Apart from moving in with their children, twelve percent of the infors. mants stated that they would like to gol back to their homeland. Twenty-five percent of the informants stated that they would move into a nursing home. Of this group, a number preferred to take this alternative in preference to moving into an extended family unit where they thought they would be a burden on their children. On the other hand, a few informants expressed fear at having to end their lives in a nursing home, and stated they wcluld not be moving even in the event of requiring constant care. It is this portion of the $\mathrm{Yu}$ goslav-born senior citizens tclgether with their familes who need to be well acquainted with all aspects of home help and domiciliary services. In addition, mainstream home help and domiciliary services must ensure their services meet the needs of this group adequately and that they are reaching this sector of the community. Table 12 summarises the informants future accommodation needs.

\subsection{Views on Government Funded Accommodation}

Informants were asked whether they thought it apprctpriate that the Australian government provide funding for a retirement village for senior citizens. Eighty-two percent stated 'yes', seventeen percent stated that they did not know while one informant answered 'no'.

Those who welcomed the concept of a retirement village for senior citizens were asked for their views on how these should be organised. Fifty percent stated that everyone, regardless of background, should live there. Eight percent felt they would prefer Europeans to be grouped together in one re tirement village. Eighteen percent preferned a retirement village for people of Yugoslav background, while five percent wanted these to be even more specialised for people of their ctwn ethnicity such as Slovenian. 
Table 12

Informants future accommodation needs

\begin{tabular}{lcc} 
Future Accommodation & $\begin{array}{r}\text { Assuming } \\
\text { No Health } \\
\text { Problems }\end{array}$ & $\begin{array}{c}\text { In Case } \\
\text { Of } \\
\text { Requiring } \\
\text { Constant } \\
\text { Care }\end{array}$ \\
\hline Moving in with son and family & $75.0 \%$ & $25 \%$ \\
Moving in with daughter \& family & 0 & $17 \%$ \\
Moving back to the homeland & $8.0 \%$ & $12 \%$ \\
Independent living unit & $1.5 \%$ & 0 \\
Nursing home accommodation & 0 & $25 \%$ \\
Would not consider moving & $14.5 \%$ & $21 \%$ \\
\hline Total & $100.0 \%$ & $100 \%$ \\
\hline
\end{tabular}

Of those who supported this concept, fifty-five percent stated that they themselves would live there while eight percent preferred to remain in their own homes.

\subsection{Availability of Suitable Accommodation}

In response to the growing number of enquiries relating to accimmodation needs, twenty private hospitals, thirty private nursing homes and thirty-five special acoommodation homes were contacted in order to identify those places with either proprietors, staff members or patients kf Yugoslav background, a situation which would enable the Yugoslav-born senior citizens to communicate in their native language.

Private hospitals offered only short term accommodation with staff members working in shifts which provided an uncongenial situation for those $\mathrm{Yu}-$ goslavs who could not express themselves in English. Hospital officials in ge neral did not keep records of which staff members spoke another language, nor did they distinguish between the official languages spoken in Yugoslavia. Staff members who were able to speak another language were discouraged by hospital policy to use their skills because of the high demand for interpreting which would take them away from their regular duties, their lack of training in the area of interpreting, and the low enumeration rebate for such work. (For a detailed discussion refer to pp. 91-2 of the original report).

The six private nursing homes in which staff of Yugoslav background worked are listed on pp. 95-6 ctf the original report. The most significant point to note is the general consensus among the Private Nursing Home officials. They agreed that the inability to communicate leads to visible physical and mental deterioration of the patient. Some officials stated that they encouraged families of non-English speaking patients to visit every day and even twice a day (different family members). One male nurse stated that nitn English speaking patients deserve and require more frequent family visits than their English speaking counterparts who were able to make friends among the staff members and that such personal relations were observed to keep the patient calm and content.

Eight special accommodation homes with Yugoslav proprietors and/or residents are listed on pp. $98-9$ in the original repclrt. It is valuable to note the past experiences of three non.1Yugoslav proprietors who had cared for Yugoslav residents. They each recalled having extreme communication difficulties. 
One resident went back to Yugoslavia to be cared for by her family there. One had a relapse two weeks after her admission and was transferred to a hospital. Ancther had dementia and after spending one weekend at the home where she could not be properly cared for, had to be sent back to her daughter who also was not able to properly care for her in addition to the apparent presence of personal tensions between the mother and daughter.

When circumstances, such as increasing frailty, being childless, the death of their children, the children's clutright rejection, or the sense of being superfluous in their children's household, force them to move to an Anglo-Australian nursing home, they find themselves in an alien environment in which they cannot express themselves. This holds for not only those elderly persons who never learned to speak English, but also fur those who with advaticing years revert to their first language $(5 ; 13)$. The findings clearly suggest that in these instances, an ethnic elderly home is preferable to the forcible immersion of aged ethnics in the existing Anglo-Australian institutions. Urgent steps must be taken by the AYWS and other government bodies to alleviate the unacceptable situation presently faced by the Yugoslaviborn elderly in Melbourne.

\subsection{Conclusion and Recommendations}

The 1981 and 1986 Australian Census of populatich and housing provide concrete statistical evidence showing a dramatic rise in the number of $\mathrm{Yu}$ goslav-born persons aged 60 years and over within this period. This increase is predicted during the next decade resulting in approximately one third of the Yugoslav-born population in Australia, attaining the age of 60 or more by the year 2001.

These statistical facts and the report findings can no longer be ignored by mainstream service providers who have so far maintained that the Yugoslav-born elderly are adequately lkloked after by their families and their communities as evidenced by the fact that they under-utilise existing mainstream services.

The present report demonstrates that a significant proportion of Yugoslav-born men and women are in desperate need of domiciliary services such as home help and meals on wheels, health services such as eye and hearing care, social contact with peers as well as financial assisiance. The large majority are prevented from using mainstream services due to their poor command of the English language, lack of mobility and insufficient information about what is available and how to become involved. Those who manage to ovierdome these difficulties frequently encounter that the service does not meet their specific needs.

It is for these reasons that the Yugoslav-born elderly depend so heavily on the families who in turn feel obligated to provide assistance even when they are themselves experiencing hardship. With so much pressure being placed on the families of the Yugoslav-born elderly, it is conceivable that family tensions may, and do result as the author witnessed in a number of cases.

Being well aware of the sclurces of potential family conflicts, many informants prefiarred to move into nursing home accommodation, rather than burdening their families, in the event of requiring constant care. There are others who are childless or for some other reason unable to depend an assistance from their children. However, the inadequacy of nursing home accommodation, suitable to meet the needs of the Yugoslav-born elderly, is nothing shcrt of dismal. 
An alarmingly high proportion of the Yugoslav-born populatikln less than 60 years of age face similar disadvantages to their ichronologically counterparts. This is primarily due to the high incidence of work related injuries among the Yugoslav-born sample population. This finding has profound consequences for their future and must be investigated in a separate study. Many informants among this group have worked hard to own their own home and car or are paying off a home mortgage or car loan as well as having to meet the associated maintenance and running costs, and therefore face additicinal $f$ nancial responsibilities which they will not be able to fulfil on a pension or benefit. These people face psychological trauma and fear of losing everything they had worked for.

All of these findings are contradictory to the Commonwealth Government's 'residential care program' which aims to ensure access by frail aged and disabled people to services which will promote their independence (1). The two key objectives of this program are to provide a range of accommodation and care services to meet the assessed needs of aged per. sons and to promote their quality of life. This research study has illustrated that the aims of the 'residential care program' have not been fulfilled according to the experiences of Yugoslav-born elderly in Melbourne.

Furthermore the Cxmmonwealth Government has on the 26th of July 1989 launched a 'National Agenda for a Multicultural Australia', which admits that "In the past, Australia has not always planned adequately for the changes and challenges brought about by a changing population*. The National Agenda is $m . .$. a set of policies to help us better manage our national diversity, to ensure that we all enjoy the same rights and to help our organisations adjust to our changed society«. It promises that »Government services will be more accessible, particularly in the areas of health and aged care and community servticesis. If these policies are to attain real meaning then we must all take notice of the present findings illustrating the current situation affecting the Yugaslav-born aged and take immediate aiction toward resolving this state of affairs and developing plausible strategies aimed at their long term resolution.

In line with other research (16), the present study has found that despite the social and demographic changes in Australian society brought about by the large influx of non-English speaking immigrants, the 'macro structure' of government institutions has largely retained its Anglo-Saxon characteristics which does not fit the 'micro structure' of many minority communities. Local government organisations, in fact, play the key role in planning, coordination and delivery of services to elderly people, yet are unable to recruit ethnic welfare workers who are currently funded by the Federal Department of Immigration and Ethnic Affairs under the 'Grant-in-aid' program (4). Clearly, coordination between the 'macro structure', and the 'micro structure' must be improved if better service provisictn for the whole community is going to be achieved. At the present, the 'macro structures' are too large to match the specific needs of minority communities while the 'micro structures' which can cope with day to day problems do not have the necessary resources to design long term strategies and solutions. A coordinating body which consits of experts qualified to implement government policy but at the same time is intimately acquainted with the specific problems and needs of the Yugoslav commulaity ought to be established within the auspice of the present education system linked to existing university departments already involved in provi, ding services to the ethnic community. This arrangement would also prctvide the best environment for further research into the Yugoslav community as 
well as having a mechanism for the implementation and monitoring of newly developed policy. Such an organisation would nct only advance the goals of the 'National Agenda', it would fulfil them.

The following are offered as recommendations towards which social planning should be directed with the goal of increasing the quality of life among the Yugoslav-bctrn population in the Melbourne metropolitan area. $\mathrm{I}_{i}^{2}$ is hoped that the present political climate, as voiced by the Prime Minister in the 'National Agenda for a Multicultural Australia', will aid and carry through these recommendations and encourage others to look more closely into the needs of the Yugoslav community in Australia.

1. A publicity campaign explaining services provided by AYWS and the mainstream service provides, especially those relating to senior citizens must urgently be undertaken. Such a campaign must be directed nolt only at the senior citizens but also at their immediate families. The success of currently available and newly planned services depends on the community's receptiveness to such services.

2. AYWS must assume a consultative and urging role with local government authorities to ensure that presently available support systems are reaccessed in light of the present findings such that services do indeed enable families of Yugoslav background to maintain their ctwn traditions and care for their frail and aging parents at home.

3. Additional support systems need to be developed for the Yugoslav-born community, including a consultation suite which could be used on a shared basis by doctors, dentists, lawyers, social and welfare workers and other professionals who speak the Yugoslav languages. Other professionals who may need tol be consulted but who do not speak the Yugoslav languages could work in conjunction with the bilingual profe. ssional staff. These suites could be equipped with a 'conference telephone system' in the event of requiring ecinsultation with outside experts who may or may not speak a Yugoslav language. A full time translator/interpreter could be employed to help clients with a lack of English speaking ability to understand official correspondence and write replies where appropriate. This type of arrangement would provide the most efficient service to the whole Yugoslav community whilst being extremely cost effective.

4. Nursing home type accommodatich suitable for the frail Yugoslav-born elderly must be established. In doing so, we must consult with the Yu goslav-born elderly to ascertain what they want, not what we think is best for them.

5. A Meals on Wheels service offering a Yugoslav cuisine approved by a dietician needs to be developed.

6. A committee should be set up within the auspice of the AYWS in cldcr to investigate ways and possibilities of utilising and sharing the unique talents of the Yugoslav-born elderly, which would minimise their isolation and maximise their sense of worth.

7. A research study into the working conditions and related injuries among the Yugaslav population needs to be carried out.

8. Multilingual and mobile libraries need to be established. Senior citizens' centres could provide the ideal venue for the dissemination of library books.

9. Tax rebates and subsidies should be made available to families caring for their elderly parents at home. 
10. Educators need to ensure that future professionals are given an insight into crosscultural ocmmunication difficulties, and trained to recognise and resolve these difficulties with the aid of specially developed resources. The recently developed Centre of Community Languages in the Professions at Monash University has begun work in this field.

11. Educational institutions must prctvide a congenial study environment for future professicinals of non English speaking background to enable them to maintain and develop their native language skills to a level required in their professional field. This may easily be achieved through the joint cooperation of various university departments by allowing these students to incorporating language unit into the overall study prigram.

12. Institutions training future translators and interpreters need to sensitise their students to the needs of the elderly in their community and develop practical training skills specific to these needs.

13. Pre-retirement programmes must be developed in order to encourage and assist Yugoslav-born people to plan their retirement.

14. It is necessary for the diverse Yugoslav community tcl reciprocate the aims of the policy of multiculturalism and show the government that they are able to work together on issues such as community welfare, the aged and others. Experience has shown that governments provide greatest sup. port to those communities which are able to coordinate themselves and demonstrate cohesion.

15. Ongoing research into the changing needs of the Yugoslav-born elderly must be undertaken. Future generations of Yugoslav-born elderly will invariably have different requirements and present support systems must be modified and new ones planned to meet those needs.

\subsection{Latest Develcpments}

The following major developments have taken place at the AYWS since the publication of the original report in 1985 .

1. An aged care worker has been emplctyed by the AYWS who is in close contact with the Home and Community Care Services program in the Dan. denong, Footscray, Keilor, Preston, Springvale and Whitlesee Councils. The Broadmeadows and Sunshine Councils will be incorporated intol the list next year. The basic aim of working with these councils is to enisure access by the Yugoslav-born senior citizens to Home and Community Care Services such as home help and meals on wheels.

2. The Dandenong Council is in the process of incorporating a continental menu in their Meals on Wheels Service. The recipes were provided by the AYWS and were approved by a dietitian before the meals were tested at the Springvale Yugoslav Senic' Citizens' Club which is run by the club members and will soon be available to the general public and especially those of Yugcklav background.

3. There are now three senior Citizens' Centres for the Yugoslav community coordinated by staff from AYWS. These are in the Reservoir, Springvale and Yarraville metropolitan regions. The Reservoir Senior Citizens' Club was established during the course of the original research project (1984-85) by a welfare wctrker from AYWS and the present author. Having begun with seventeen members, membership at that club has now exceeded one hundred. The Yarraville Senior Citizens' Centre has recently gained approval to share the premises at the local Senior Citizens' Centre. This sign of acceptance is considered quite a breakthrough by the Yugoslav community. 
YUGOSLAVIA: REPUBLICS AND AUTONOMOUS PROVINCES.

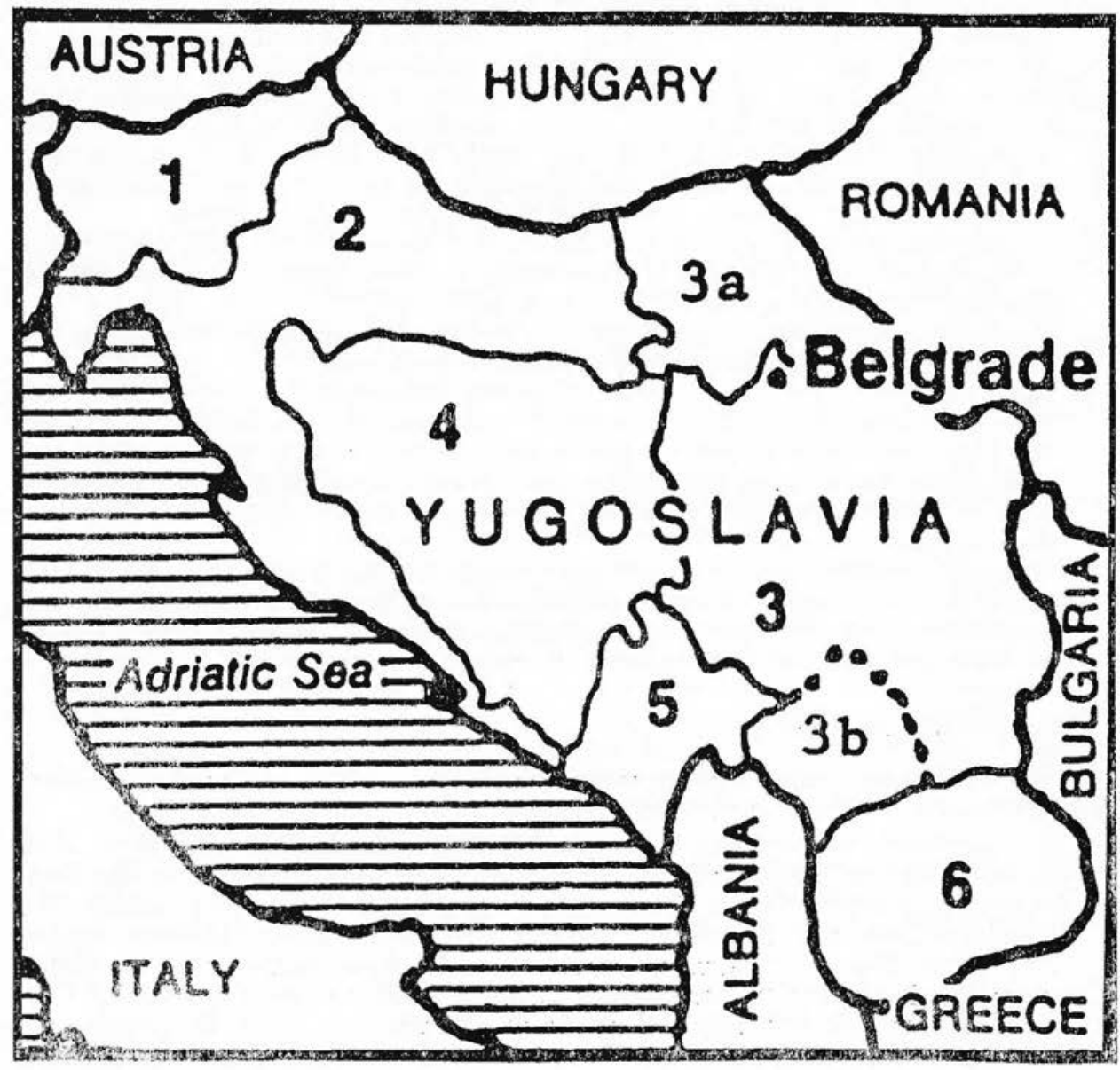

Map 1. This map shows the republics and autonomous provinces of Yugoslavia and the border natictns with which many Yugoslavs have lin. guistic, religious and cultural ties.

\begin{tabular}{lll}
\hline REGION & OFFICIAL LANGUAGES IN USE & INTERNATIONAL DESIGNATION \\
\hline 1. Slovenia & Slovenian/Slovene, Serbo-Croatian Slovenian, Serbo-Croatian \\
2. Croatia & Croatian & Croato-Serbian, Serbo-Croatian \\
3. Serbia & Serbo-Croatian & Serbo-Croatian \\
3a. Vojvodina & Serbo-Croatian, Hungarian, & Serbo-Croatian \\
3b. Kosovo & Romanian, Rusinian & Serbo-Croatian \\
4. Bosnia and Serbo-Croatian, Albanian & \\
\multicolumn{2}{l}{ HerzegovinaSerbo-Croatian } & Serbo-Croatian \\
5. Montenegro Serbo-Croatian & Serbo-Croatian \\
6. Macedonia Macedonian, Serbo-Croatian & Macedonian, Serbo-Croatian \\
\hline
\end{tabular}




\section{APPENDIX B}

PERMANENT AND LONG TERM YUGOSLAV ARRIVALS 1945-88

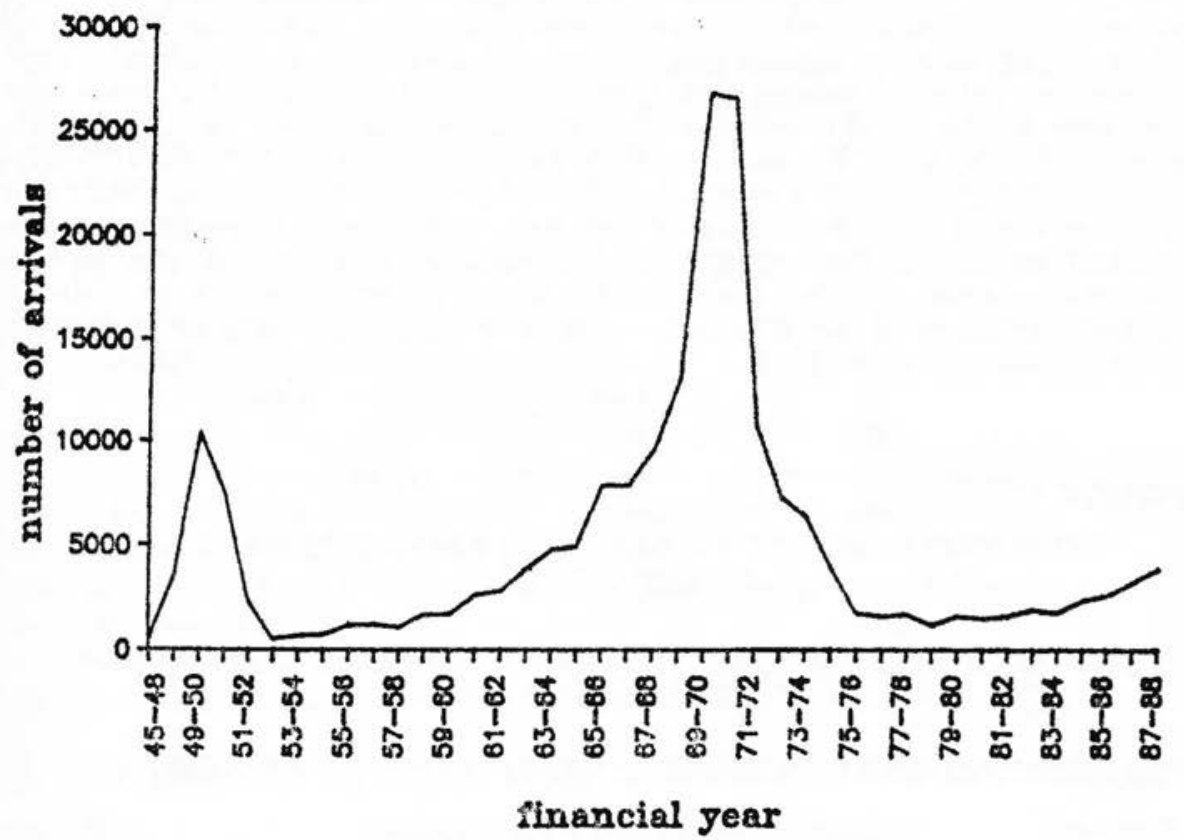

Graph 1. Permanent and long term arrivals af Yugoslav citizenship: 1945-88. (Source: Department of Immigration, Local Government and Ethnic Affairs, 1971, 1978, 1983, 1988 and 1989)

4. Another important development is the planning of a 60 place Hulstel in Sunshine. A submissic'n for this project is currently being prepared by a project office at AYWS employed for this task. The project will be a joint venture between the Department of Community Services and Health and the Macedonian Community of Footscray who are donating the land. The hostel will be open to all ethnic groups.

5. People wurking with the Yugoslav community as well as the general public will have an opportunity to learn more about the people from Yugoslavia and their culture during a Yugoslav Cultural Day planned for the 29 th of September at Springvale.

6. A Conference on issues relating to the Yugoslav community in Australia will be planned for late 1989 . The conference will be aimed at providing prcfessionals working with the Yugoslav community with the opportunity to exchange ideas and develop new strategies for meeting the needs of the Yugoslav community.

For further information about these and other planned events contact the staff at AYWS. 
As far as the author could ascertain, a single table of permanent and long term arrivals of Yugoslav citizenship, from 1945-88, is not available. It was therefore necessary to draw the relevant information frctm a number of publications produced by the Department of Immigration, Local Governmentt and Ethnic Affairs (DILGEA) whe in conjunction with the Australian Bureau of Statistics (ABS) have produced publications of statistical information. There is however an inherent problem in compiling data from various sources and publications due to the difference in the terminology used and method of data collation. Initially, DILGEA and the ABS had a different definition of "settlers* which became uniform only after 1985. Furthermore there are different criteria for classifying the origin of arrivals: birthplace, citizenship (nationality) and country of last residence. Citizenship at the time of arrival was the criteria selected for the plotting of the above graph which provides a visual representation of the WW II molvement of settler and long term arrivals Yugaslav citizenship up to 1988.

\section{APPENDIX C}

\section{SELECTED SAMPLE OF QUESTIONS FROM THE ORIGINAL QUESTIONNAIRE}

\section{NEEDS OF THE ELDERLY YUGOSLAVS IN THE MELBOURNE METROPOLITAN AREA}

\section{DEMOGRAPHIC VARIABLES - PERSONAL DETAILS AND HEALTH}

1. Gender?

2. Age?

4. Length of residence in Australia?

5. Age on arrival to Australia?

6. Which republic were you born in?

7. Marital status?

8. If widowed, divoroed or separated - did you encounter any problems or difficulties as a result of this situation?

9. Did anyone assist you with these difficulties?

10. Whol helped you and what did they do for you?

11. How many children do you have living in Melbourne, elsewhere in Australia and abroad?

12. What is your citizenship?

13. How would you access your overall health?

14. Does your health condition place any restriction on your manoeuvrability?

15. Is this health condition wctrk related?

\section{SOCIAL CONTACT - SUPPORT FROM FAMILY AND FRIENDS, LEISURE ACTIVITIES}

16. How many family members do you have living in Melbourne?

17. How often do you see these family members?

18. Are you happy with the amount of time you have to spend with your family?

19. What assistance does your family (generally) provide for ycu? 
20. What assistance (if any) do you provide for your family?

21. Do friends assist you and how?

22. Which individual do you rely upon the most?

23. How much time do you spend on ychur own?

24 . What do you occupy yourself with in your spare time?

25. Are you a member of any social club or senior citizens association?

26. Which activities would you like to be involved in?

27. Do' you feel lonely?

28. What causes you greatest concern?

III EDUCATION, EMPLOYMENT, LANGUAGE AND ECONOMIC STATUS

29. Number of years of schooling?

30. Ability to read and write native tongue?

31. Ability to speak, read and write English?

32. Have you attended English classes and for how long?

33. Would you now like to attend English classes and in what capacity?

34. What are your qualifications and where did you gain these?

35. Where did (dcl) you work?

36. How long has it been since you last worked and for what reason did you cease to work?

37. What is your overall weekly income?

38. Source of income?

\section{ACCOMMODATION, KNOWLEDGE AND USE OF EXISTING SERVICES}

39. What type of accommodation do yclu presently live in?

40. What do you intend to do about future accommodation if your health remains the same?

41. What do you intend to do about future accommcldation if you should require constant care?

42. Do you have a telephone and do you feel comfortable in using it?

43. In your opinion, do you think it would be beneficial fcr the government to provide some form of accommodation for the elderly?

44. If so, what form should it take?

45. Would you live there?

46. What oummumity services have you heard of and which do you use?

47. Would your family object to you using any of the services, which?

48. What types of foods do you normally eat?

49. Have you tried the Meals of Wheels service and how satisfied are (were) you with it?

50. Have you sought help from the Australian Yugoslav Welfare Sclciety and how satisfied were you with their assistance?

PLEASE NOTE THAT THE COMPLETE QUESTIONNAIRE (APPENDIX N OF THE ORIGINAL REPORT) CONSISTS OF 88 QUESTIONS, MANY OF WHICH HAVE SUBSECTIONS. THE ABOVE SAMPLE HAVE BEEN ADAPTED FOR THE PURPOSE OF THE PRESENT REPORT AND ARE NOT INTENDED AS A READILY USABLE TOOL. 


\section{BIBLIOGRAPHY}

1. Australian Bureau of Statistics, Year Book Australia, Canberra, 1988.

2. Australian Institute of Multicultural Affairs, The Ethnic Aged, An Annotated Bibliography and Selected Statistics, Melbourne, June 1983.

3. Borković, R., The Needs of Elderly Yugoslavs in the Melbourne Metropolitan Area, Victorian Ethnic Affairs Commission, 1985.

4. Brewer G., Ethnic Aged and Local Government. A study of the needs in Italian and Greek aged residents in the municipalities of Northcote and Brunswick, March, 1985.

5. Clyne, M., 'Bilingualism of the elderly', Talanya, iv (1977), pp. 45-56.

6. Committee of Review of the Australian Institute of Multicultural Affairs, Report to the Minister for Immigration and Ethnic Affairs, Volume I, 1983.

7. Department of Immigration, Government and Ethnic Affairs, Australian Immigration - Consolidated Statistics: No. 5, Canberra, 1971, No. 10, Canberra, 1978, No. 13, Canberra, 1983, No. 14, Canberra, 1988 and No. 15, Canberra, 1989.

8. Ethnic Education Census, Yugoslavia Language Schools Populations, (Eastern, Western and Northern metropolitan regions), 1983.

9. Guthrie, R. V., What do They Need, An Enquiry Into the Needs of Aged Italians in the Melbourne Metropolitan Area, CO.AS.IT Research Monograph No. 1, 1983.

10. Health Commission of Victoria, Extended Care of Aged or Disabled Persons, July, 1982.

11. Hearst, S., Ethnic Communities and their Aged, 1981.

12. Martin, J. I., Refugee Settlers: a study of displaced persons in Australia, ANU Press, 1965.

13. Moraitis, S., 'The migrant aged', Australian Family Physician, Vol. 8, April 1979 , pp. $399-405$.

14. Office of Multicultural Affairs, National Agenda for a Multicultural Australia, Australian Government Publishing Service, Canberra, July, 1989.

15. Overberg, H., Dutch Aged in Victoria, Victoria, College, Melbourne, August, 1984.

16. Smolicz, J. J., Culture and Education in a Plural Society, Curriculum Development Centre, Canberra, October, 1979.

17. Spaseski, B., A Report on the W. A. Yugoslav Homes for the Aged Project, October, 1984.

18. The Victorian Council on the Aging. What's the Answer? An Introduction to the Range of Accommodation and Service for Elderly People in Victoria, February, 1983.

\section{POTREBE STARIJIH JUGOSLAVENA NA METROPOLITANSKOM} PODRUCJU MELBOURNEA

\section{SAŽETAK}

Prezentirani tekst sociološka je rasprava o problemima i potrebama starije generacije (izrsad 60 godina) doseljenika rođenih u Jugoslaviji na širem području Melbournea u okruženju nove sredine i mlađeg doseljeničkog pokoljenja.

Polazeći od demagrafskog profila populacijskog uzorka, autorica podvrgava objektivnoj kritici sve važnije (ekonomske, zdravstvene, kulturne, socijalne, obrazovne i dr.) probleme starije generacije.

Posebni dio teksta čini složeno pitanje recentne realizacije potreba starije doseljeničke generacije. 